\title{
The Impact of Tax Collection in Achieving Revenue Targets: The Directorate General of Taxes of Mali Case Study
}

\author{
Sekou Maiga \\ Economics and Management School, Wuhan University, Wuhan, China \\ Email: sekouma17@yahoo.com
}

Received 5 April 2015; accepted 1 June 2015; published 4 June 2015

Copyright (C) 2015 by author and Scientific Research Publishing Inc.

This work is licensed under the Creative Commons Attribution International License (CC BY). http://creativecommons.org/licenses/by/4.0/

(c) $\underset{\mathrm{EY}}{\mathrm{i}}$ Open Access

\begin{abstract}
In this case study we examine the relationship between the collection of taxes and revenue targets generated by each of the Financial Services at the Directorate General Taxes of the Republic of Mali. Revenues generated by the Directorate General of Taxes contributed a big chunk of funds to the Malian Treasury, about $40 \%$, with our focus being on the year 2012. After economic modeling and estimation, we realized that there is a positive correlation between tax collection changes and the revenues generated. The estimates of the revenue growth model of Directorate General of Taxes in Mali show that it's influenced by changes in the collections of taxes.
\end{abstract}

\section{Keywords}

Source of Revenue, Wealth of Citizens, Social Responsibilities of Government, Tax Administration, Positive Correlation

\section{Introduction}

According to [1] Taxation imposes welfare costs on individuals which, expressed in money terms, exceed the tax paid. This gives rise to the idea of the excess burden of taxation, which is one of the most important concepts in public economics. It represents an efficiency loss caused by distortion in choices arising from a change in relative prices. Tax revenue is used to finance government expenditure on a range of projects as well as paying for transfer payments, such as benefits to specified low-income households. Since the burden imposed on taxpayers exceeds the tax they pay, it is important to ensure that the perceived benefits arising from government expenditure are sufficient to outweigh the efficiency losses.

Taxation is seen as a burden which every citizen must bear to sustain his or her government, because the gov- 
ernment has certain functions to perform for the benefits of those it governs. A precised definition of taxation by [2] is that taxation is one of the sources of income for government, such income as used to finance or run public utilities and perform other social responsibilities. [3] defines tax as a levy imposed by the government against the income, profit or wealth of the individuals and corporate organizations.

According to [4] taxation is the most important source of revenue for modern governments, typically accounting for ninety percent or more of their income. Taxation is seen by [5], as a compulsory levy by the government through its agencies on the income, consumption and capital of its subjects. These levies are made on personal income, such as salaries, business profits, interests, dividends, discounts and royalties. It is also levied against company's profits, petroleum profits, capital gains and capital transfer. Whereas, [6] stresses that, taxation is a concept and the science of imposing tax on citizens. According to him, tax is itself a compulsory levy which is required to be paid by every citizen. It is generally considered as a civic duty. The imposition of taxation is expected to yield income which should be utilized in the provision of amenities, both social and security and creates conditions for the economic wellbeing of the society.

[7] states that income tax can be regarded as a tool of fiscal policy used by government all over the world to influence positively or negatively particular type of economic activities in order to achieve desired objectives. The primary economic goals of developing countries are to increase the rate of economic growth and hence per capita income, which leads to a higher standard of living.

Progressive tax rate can be employed to achieve equitable distribution of resources.

Government can also increase or decrease the rates of tax, increase or decrease the rate of capital allowances (given in lieu of depreciation) to encourage or discourage certain industries (e.g. in the area of agriculture, manufacturing or construction) or may give tax holidays to pioneer companies. Income tax therefore can be used as an agent of social change if employed as a creative force in economic planning and development.

A tax administration is the whole organizational set-up for the management of the tax system. The tax administrative set-up is a department of government and of course works under regulations prescribed by tax legislation. Tax administration is the process of assessing and collecting taxes from tax individuals and companies by authorities in such a way that correct amount is collected efficiently and effectively with minimum tax avoidance or tax evasion.

The broad objectives of a tax system is to guarantee the long-run fiscal soundness of the policies and programs of government while the purpose of tax administration is to fully implement the tax system, that is, to ensure that tax payers comply with the provisions of tax laws and that the funds derived from tax sources are paid into the government purse. Certain aspects of the tax system are preconditions for a successful tax administration. First the tax laws should be simple, clear and understandable both to those who must apply them and those who are subject to them. To quote [8], the tax which each individual is bound to pay ought to be certain and not arbitrary. The form of payment, the manner of payment, the quantity to be paid ought all to be clear and plain to the contributor and every other person.

The scope of tax should also be clear. It should be certain that the tax can and will be enforced, for a tax that is easily evaded causes resentment among the honest taxpayers and often decline in taxpayers' morality. Secondly, the taxes should be fair, that is the burden should be spread as fair as possible, with regard to the taxpayer's ability to pay and in light of his family circumstances, obligations and wealth. The taxes should also be equitable as between one tax payer and another; they should be of universal (general) application, and imposed without distinction of persons between citizens in similar circumstances.

Thirdly, the taxes should be easy, economical and convenient to administer that is the cost of collecting to the tax authority and the cost of compliance to the taxpayer should be as low as possible and should be consistent with effective enforcement which means that the purpose and manner of payment of the taxes should be related to the habits of the community. Hence the colonialists were careful enough to introduce taxes as closely connected as possible to what their native laws had been paying to their chiefs in those areas where such was the practice [9].

The role of the tax administrator in this matter is a crucial one. [10] has pointed out that subject to the direction of the government and the will of the legislature, the purpose of the tax administrator is, to devise taxes in conformity with the principles that will raise revenues sufficient to meet the needs of government to establish the basis of assessment and a procedure for collection that are as simple, effective and economical as possible, and to develop auditing and other procedures.

The function of a tax administrator also includes ensuring full compliance and effective enforcement of tax 
matters by tax payers.

It is important to note that however good principles of a tax system may be, the success of tax administration depends essentially on the ability of the tax administrators to utilize the principles. The problem of personnel then becomes central to tax administration. Hence it has been argued according to [11] that the problems of tax administration in underdeveloped countries are basically problems of personnel; there is usually poor pay, lack of training, inefficiency and understaffing.

For development and growth of any society, the provision of basic infrastructure is quite necessary. This perhaps explains why the government shows great concern for a medium through which funds can be made available to achieve their set goals for the society [12]. Government needs money to be able to execute its social obligations to the public and these social obligations include but not limited to the provision of infrastructure and social services. According to [13], meeting the needs of the society calls for huge funds which an individual or society cannot contribute alone and one medium through which fund is derived is through taxation. Tax is a major source of government all over the world. Government use tax proceeds to render their traditional functions, such as the provision of public goods, maintenance of law and order, defense against external aggression, regulation of trade and business to ensure social and economic maintenance [14] [15].

According to [16], four key issues must be understood for taxation to play its functions in the society. First, a tax is a compulsory contribution made by the citizens to the government and this contribution is for general common use. Secondly, a tax imposes a general obligation on the tax payer. Thirdly, there is a presumption that the contribution to the public revenue made by the tax payer may not be equivalent to the benefits received. Finally, a tax is not imposed on a citizen by the government because it has rendered specific services to him or his family. Thus, it is evident that a good tax structure plays a multiple role in the process of economic development of any nation which Nigeria is not an exception [17] [18] note that these roles include: the level of taxation affects the level of public savings and thus the volume of resources available for capital formation; both the level and the structure of taxation affect the level private saving. A system of tax incentives and penalties may be designed to influence the efficiency of resource utilization; the distribution of the tax burdens plays a large part in promoting an equitable distribution of the fruit of economic development; the tax treatment of investment from abroad may affect the volume of capital inflow and rate of reinvestment of earnings there from; and the pattern of taxation on imports relative to that of domestic producers affect the foreign trade balance. However, [19] pointed out that there are three basic objectives of taxation. These are to raise revenue for the government, to regulate the economy and economic activities and to control income and employment. Also, [16] noted that taxes generally have allocational, distributional and stabilization functions. The allocation function of taxes entails the determination of the pattern of production, the goods that should be produced, who produces them, the relationship between the private and public sectors and the point of social balance between the two sectors. The distribution function of taxes relates to the manner in which the effective demand over economic goods is divided, among individuals in the society. According to [20], the distribution function deals with the distribution of income and wealth to ensure conformity with what society considers a fair or just state of distribution. The stabilization of function of taxes seeks to attain high level of employment, a reasonable level of price stability, an appropriate rate of economic growth, with allowances for effects on trade and on the balance of payments. [21] argues that the scope of these functions depends, inter alia, on the political and economic orientation of the people, their needs and aspirations as well as their willingness to pay tax. Thus, the extent to which a government can perform its functions depends largely on the ability to design tax plans and administration as well as the willingness and patriotism of the governed.

According to [22], the principles of taxation mean the appropriate criteria to be applied in the development and evaluation of the tax structure. Such principles are essentially an application of some concepts derived from welfare economists. In order to achieve the broader objectives of social justice, the tax system of a country should be based on sound principles. [23]-[25] listed the principles of taxation as equality, certainty, convenience, economy, simplicity, productivity, flexibility and diversity.

Equity principle: states that every taxpayer should pay the tax in proportion to his income. The rich should pay more and at a higher rate than the other person whose income is less [22] [23] states that it is only when a tax is based on the tax payer's ability to pay can it was considered equitable or just. Sometimes this principle is interpreted to imply proportional taxation.

Certainty principle: of taxation states that a tax which each individual is bound to pay ought to be certain, and 
not arbitrary. The time of payment, the manner of payment, the quantity to be paid ought to all be clear and plain to the contributor and every other person [24].

The tax recipes constitute the principal and reliable national financial resources. They can not only provide an important service required by finance, but also ensure the good functioning of the public institutions and the promotion of the economic development. Effective fiscal authorities, the high efficiency and its competence are therefore absolutely necessary to mobilize the national budget resources and to furnish the government of the durable and generated recipes in an internal way. These can reduce dependence on foreign investment and assistance to economic development.

A pressing attention must be granted to the realization of the objectives of recipes of the year for the constitution of the national budget. It leaves respect of the internal and exterior engagements to the government.

The Directorate General of Taxes is one of the biggest services sources of recipes to the National Treasury, it depends on The Directorate General of Taxes that our country owns a relatively stable social and political environment. Because of the deterioration of the relations with the bond stakeholders, social economy is relatively difficult; the Directorate general of Taxes remains stable with the support of the National Bank.

\section{Duties and Responsibilities of the Directorate General of Taxes of Republic of Mali}

The Directorate General of Taxes is a service department of the Ministry of Finance created by Act No. 84 - 25 AN-RM of 21/07/1984, and according [4], its mission is to 1) present tax legislation relating to taxes, duties and to ensure its implementation; 2) liquidate, control and collect taxes and duties levied in favor of the State; 3) present legislation relating to land, crown and cadastral regulations. Revenues from Directorate General of Taxes consist mainly of tax revenues which include direct taxes, indirect taxes, registration fees and stamps. There are different kinds of taxes: direct, indirect etc.

Direct tax: tax paid by the individual or organization on whom it is levied. For example, the personal income tax is levied on individuals, who end up bearing the entire burden of the tax. A direct tax cannot be shifted from the entity on which it is levied.

Indirect tax: a tax paid by an entity other than the one on which it is levied. For example, a retail sales tax is collected and remitted to the government by a business even though the tax is ultimately paid by the consumers. The taxes mainly recovered are; corporate income tax, tax on industrial and commercial profits, value added tax, tax on insurance contracts, registration fees, stamp tax, tax income securities.

Directorate General of Taxes of Mali has achieved in 2010 revenues amounting to approximately 740 million US dollars after a target of 734 million US dollars, which had been assigned by the government of Mali. Also after the outstanding performance of 854 million US dollars made by the Directorate General of Taxes under the Finance Law of 2011, Directorate General of Taxes was assigned in 2012 to achieve 990 million US dollars of tax revenue [5]. Given the economic and military crisis that followed it would have taken a miracle for the realization of this revenue target allocated for the year 2012. This was the situation of macro-economic indicators of Mali in the year 2012; economic growth drastically fell from 5.3\% in 2011 to $-1.2 \%$ (negative rate) for the year 2012. Also another unflattering indicator was that inflation increased from 3.5\% in 2011 to 5\% in 2012 (see see Figure A1 in the Appendix). Military and security crisis could have been the influencing factors in the drastic changes of the inflation rates and economic growth. Therefore we took the year 2012 as our point of reference.

Fortunately as of now the government is trying to have solutions to this crisis by establishing a fiscal framework over 3 years, from 2013 to 2015. Following this strategy, which depends largely on external financing, the government hoped to realize a growth of 7\% for the year 2013; 5.7\% for the year 2014 and 5.3\% for the year 2015. Whether these are optimistic or unrealistic goals, only time will confirm [6].

The main objectives of this study are as follows: 1 ) to show the preponderant role of tax collection in achieving revenue targets assigned to different directions; 2) to focus on the consequences of the security crisis in Mali on the macro-economic indicators; 3) to implement a good Value Added Tax (VAT) administration through improved research methods. The relationship between the collection of taxes and revenue targets generated by the Financial Services at the Directorate General Taxes of the Republic of Mali has interested us because of its paramount importance to the economic outlook of Mali. The Directorate General of Taxes in Mali estimates as looked at in this study show that the revenue growth model is influenced by changes in the collections of taxes.

The paper is organized as follows: next is Section 2 which deals with the Methodology of the study. Section 3 
is focused on Results and Findings of our research. Conclusions and Recommendations are availed in Section 4.

\section{Research Methodology}

\subsection{Data Collection}

The data collected were provided by the Accounting Management Section of the Central Accounting Agency of the Treasury (CAAT) of Mali. This is the department responsible for the supervision and centralization of all accounting transactions and financial services of the state. Daily accounting transactions are saved from all directorates using the TABOR public accounting software, that is, state accounting. The software is designed to track weekly income and expenditure of all financial administrations. The data is updated on a weekly basis.

We chose to collect data by this method because it is modern and its simplicity, reliability and consistency are advantageous to us. This method is very reasonable because the data can be captured effectively between different structures involved in the chain of command. It has the advantage of taking account balances at the beginning of year, and then continues balancing the accounts with every subsequent transaction. It is for these reasons that when it comes to tax data collection we had preference for this type of method.

\subsection{The Model}

The data were analyzed through the use of the econometric software EVIEWS. In order to evaluate the relationship between the collection of taxes and revenue targets, the following regression model was built:

$$
T Y_{t}=\beta_{0}+\alpha_{1} T E X_{t}+\alpha_{2} T M 2_{t}+\alpha_{3} D N_{t}+\alpha_{4} S A V Y_{t}+\theta
$$

where $T Y_{t}$ is considered as the dependent variable and $T E X_{t}, T M 2_{t}, D N_{t}$ and $S A V Y_{t}$ are the independent variables.

$T Y_{t}$ is the growth rate of revenue realized by the Directorate General of Taxes, $T E X_{t}$ is the Taxes recovery rate, $T M 2_{t}$ is the premium on budgetary revenues, $D N_{t}$ is the share allocated on total revenues and $S A V Y_{t}$ represents the revenue transfer slips. These variables are used mostly in the form of rates of change with respect to time.

\section{Results and Main Findings}

\subsection{Results of Estimating and His Interpretation}

The trend for the collection of taxes in 2012 shows that the largest revenue months are June and December. We have the following periods in a calendar year cycle. Analysis shows that during the first quarter (January; February and March), revenues are very low; this weakness can be attributed to lack of dissemination of tax information to citizens. The second quarter (April; May and June) revenue increases because beyond liquidation warnings, people begin to pay their tax. Third quarter (July; August and September) is the rainy season. This is a period when citizens have difficulties because of agricultural work which includes the purchase of pesticides; and the fourth quarter (October; November and December) shows recovery probably due to the sale of crops, therefore people have the means and naturally fulfill their tax obligations. We will initially estimate the model as the second step for interpreting the results.

\subsection{Parameter Estimation}

For all revenue realized by the Directorate General of Taxes, the means results we got are as follows (Table 1):

*P-values are in parentheses, $\mathrm{R}^{2}=0.72$ and $\mathrm{DW}=2.009$.

Such that the model would look like:

$$
T Y_{t}=97.71+0.119 T E X_{t}+0.012 T M 2_{t}+0.030 D N_{t}+0.492 S A V Y_{t}
$$

From these results we note that only one variable, that is the $S A V Y_{t}$ (the revenue transfer slips) is not significantly different from zero (0) since its p-value is greater than the level of significance 0.05 .

Table 1. Estimated parameters.

\begin{tabular}{ccccc}
\hline$\alpha_{1}$ & $\alpha_{2}$ & $\alpha_{3}$ & $\alpha_{4}$ & $\beta_{0}$ \\
\hline 0.119 & 0.012 & 0.030 & 0.492 & 97.71 \\
$(0.031)$ & $(0.048)$ & $(0.023)$ & $(0.074)$ & $(0.043)$ \\
\hline
\end{tabular}




\subsection{Results and Main Findings}

After the modeling and estimation we can say from the value of $\alpha_{1}=0.119$ that there is a positive correlation between the collection of taxes and revenues generated by financial services of the Directorate General of Taxes of Mali. We can also say that the estimate of revenue growth model of Directorate General of Taxes shows that it is influenced by changes in the collection of taxes. This significant and positive relationship shows that the two clusters are moving in the same direction.

Thus it confirms that all revenues from the Directorate General of Taxes in the long term depend in volatility and low amounts collected by the tax authorities. It also shows that with the current revenue structure of the Directorate General of Taxes, it would be impossible to achieve the fiscal targets fixed by the Government of Republic of Mali.

\section{Conclusions and Recommendations}

After the modeling and estimation we can say from the value of $\alpha_{1}=0.119$ that there is a positive correlation between the collection of taxes and revenues generated by financial services of the Directorate General of Taxes of Mali. We can also say that the estimate of revenue growth model of Directorate General of Taxes shows that it is influenced by changes in the collection of taxes. This significant and positive relationship shows that the two clusters are moving in the same direction.

From our results which show that under the current setup of revenue structures of the Directorate General of the Taxes it would be impossible to achieve the fiscal targets fixed by the Government of Republic of Mali, we definitely need some remedial solutions. To achieve the revenue assigned, the Tax Office must take robust measures in their effort on the collection of taxes, and implement a proper administration of VAT including the improvement of research methods and the creation of mixed brigades between financial services. The directorate can also pursue the quest for efficiency through local communication and explain and educate our economic and administrative partners about the real issues of the taxes. This would help to offer the best quality of service to users, assess the potential of different localities and give effective support to the Ministry of Economy and Finance and financial and educational support of partners. Then with the dynamic internal organization having already initiated the precepts of planning, Results Based Management and PAMORI (a program for the improvement and modernization of the taxes services) can be achieved.

\section{References}

[1] Creedy, J. and Kalb, G. (2006) Labour Supply and Micro Simulation: The Evaluation of Tax Policy. Edward Elgar, Cheltenham.

[2] Farayola, G.O. (1987) Guide to Nigerian Taxation, Ikeja. All Group Nigeria Limited Publishers, Ibadan.

[3] Ochiogu. A.C. (1994) Nigeria Taxation for Students. A.C Ochiogu Publishers, Enugu.

[4] Adams, C. (2001) For Good and Evil: The Impact of Taxes on the Course of Civilization. Madison Publishers, The Greater Manchester Area.

[5] Aguolu, O. (2004) Taxation and Tax Management in Nigeria. 3rd Edition, Meridan Associates, Enugu.

[6] Ojo, O. (2008) Franchising: Hybrid Organizational Arrangement for Firm Growth and National Development. Lex ET Scientia International Journal (LESIJ), 15, 113-120.

[7] Okon, E. (1997) Company Income Tax in Nigeria. Unpublished Monograph, University of Port Harcourt, Port Harcourt.

[8] Adams, S. (1910) The Wealth of Nations. Everyman’s Library Ltd., London.

[9] Orewa, G.O. (1979) Taxation in West and Mid-Western Nigeria. 2nd Edition, Institute of Social and Economic Research, Ibadan.

[10] Balls, O. (1965) The Problems of Tax Administration. John Hopkins Press, Baltimore.

[11] Surrey, S.S. (1965) Tax Administration in Under-Developing Countries. John Hopkins Press, Baltimore.

[12] Fagbemi, T.O., Uadiale, O.M. and Noah, A.O. (2010) The Ethics of Tax Evasion: Perceptual Evidence from Nigeria. European Journal of Social Sciences, 17, 360-371.

[13] Murkur, G.A. (2001) Design of Tax and Corruption. Proceedings of the Conference on Fighting Corruption: Common Challenges and Shared Experiences, Singapore, 10-11 May 2001, 1-9.

[14] Azubike, J.U.B. (2009) Challenges of Tax Authorities, Tax Payers in the Management of Tax Reform Processes. Nige- 
ria Account, 42, 36-42.

[15] Edame, E. (2008) The Essential of Public Finance and Public Financial Management in Nigeria. Revised 3rd Edition, Wusen Press Ltd., Calabar.

[16] Nzotta, S.M. (2007) Tax Evasion Problems in Nigeria: A Critique. Nigeria Account, 40, 40-43.

[17] Appah, E. (2010) The Problems of Tax Planning and Administration in Nigeria: The Federal and State Governments Experience. International Journal of Labour and Organisational Psychology, 4, 1-14.

[18] Musgrave, R.A. (2006) Estimating the Distribution of the Tax Burden. John Hopkins University, Baltimore.

[19] Anyanwu, J.C. (1993) Monetary Economics: Theory, Policy and Institutions. Hybrid Publishers, Onitsha.

[20] Musgrave, R.A. and Musgrave, P.B. (1979) Public Finance in Theory and Practice. 2nd Edition, McGraw-Hill Kogakusha Ltd., Tokyo.

[21] Nwezeaku, N.C. (2005) Taxation in Nigeria: Principles and Practice. Springfield Publishers, Owerri.

[22] Anyanfo, A.M.O. (1996) Public Finance in a Developing Economy: The Nigerian Case. Department of Banking and Finance, University of Nigeria, Enugu Campus, Enugu.

[23] Jhingan, M.L. (2004) Money, Banking, International Trade and Public Finance. Vrinda Publications, New Delhi.

[24] Bhartia, H.L. (2009) Public Finance. 14th Edition, Vikas Publishing House PVT Ltd., New Delhi.

[25] Osiegbu, P.I., Onuorah, A.C. and Nnamdi, I. (2010) Public Finance: Theories and Practices. C.M. Global Company Ltd., Asabi.

\section{Appendix}

REVENUE COLLECTED

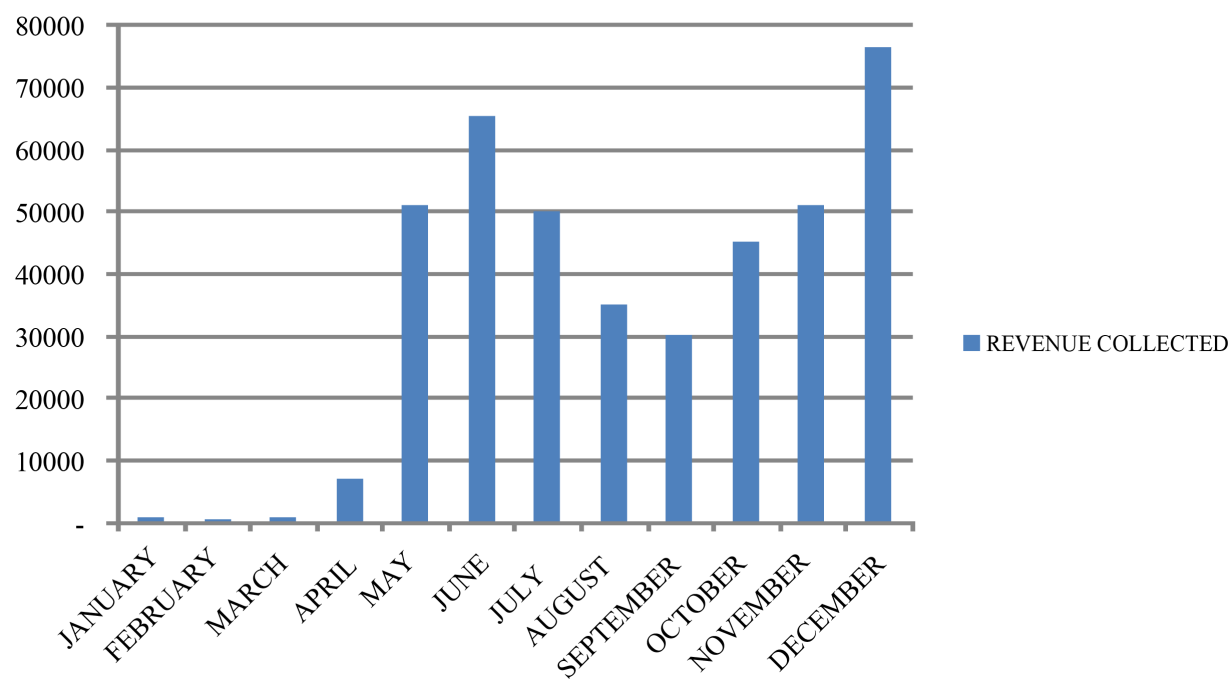

Amount in US Dollars, 2012 year, source: Section Compte de Gestion ACCT

Figure A1. Recovered taxes made by the directorate general of taxes (source: Section compte de gestion ACCT, management accounting section of ACCT). 